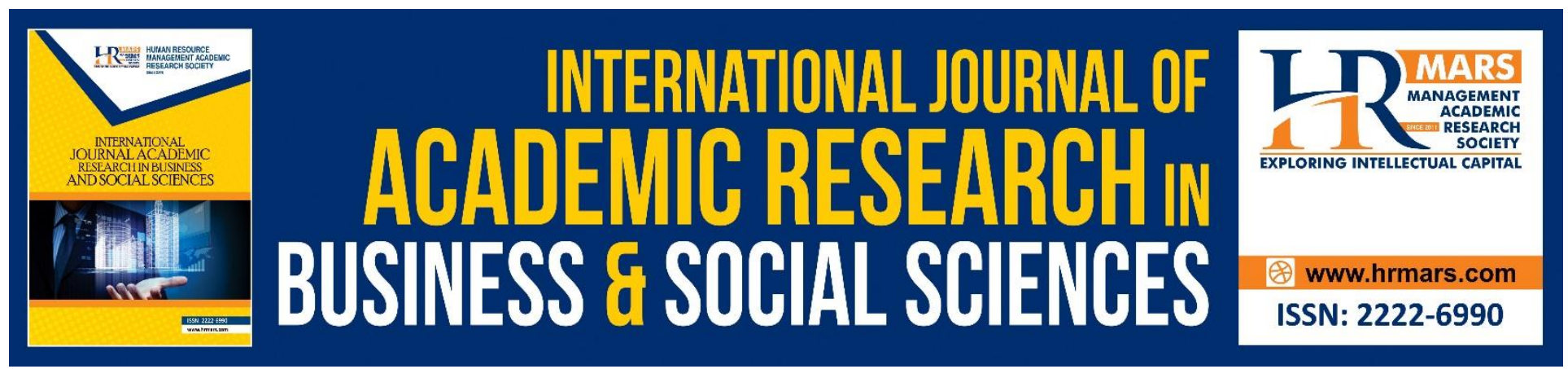

\title{
Occupational Stress, Job Satisfaction and Job Performance among Teachers: A Research Framework
}

\author{
Noor Liyana Mohd Nor
}

To Link this Article: http://dx.doi.org/10.6007/IJARBSS/v10-i5/7323

DOI:10.6007/IJARBSS/v10-i5/7323

Received: 25 March 2020, Revised: 29 April 2020, Accepted: 19 May 2020

Published Online: 27 May 2020

In-Text Citation: (Nor, 2020)

To Cite this Article: Nor, N. L. M. (2020). Occupational Stress, Job Satisfaction and Job Performance among

Teachers: A Research Framework. International Journal of Academic Research in Business and Social

Sciences, 10(5), 919-924.

Copyright: (C) 2020 The Author(s)

Published by Human Resource Management Academic Research Society (www.hrmars.com)

This article is published under the Creative Commons Attribution (CC BY 4.0) license. Anyone may reproduce, distribute, translate and create derivative works of this article (for both commercial and non-commercial purposes), subject to full attribution to the original publication and authors. The full terms of this license may be seen

at: $\underline{\text { http://creativecommons.org/licences/by/4.0/legalcode }}$

Vol. 10, No. 5, 2020, Pg. 919 - 924

http://hrmars.com/index.php/pages/detail/IJARBSS

JOURNAL HOMEPAGE

Full Terms \& Conditions of access and use can be found at http://hrmars.com/index.php/pages/detail/publication-ethics 


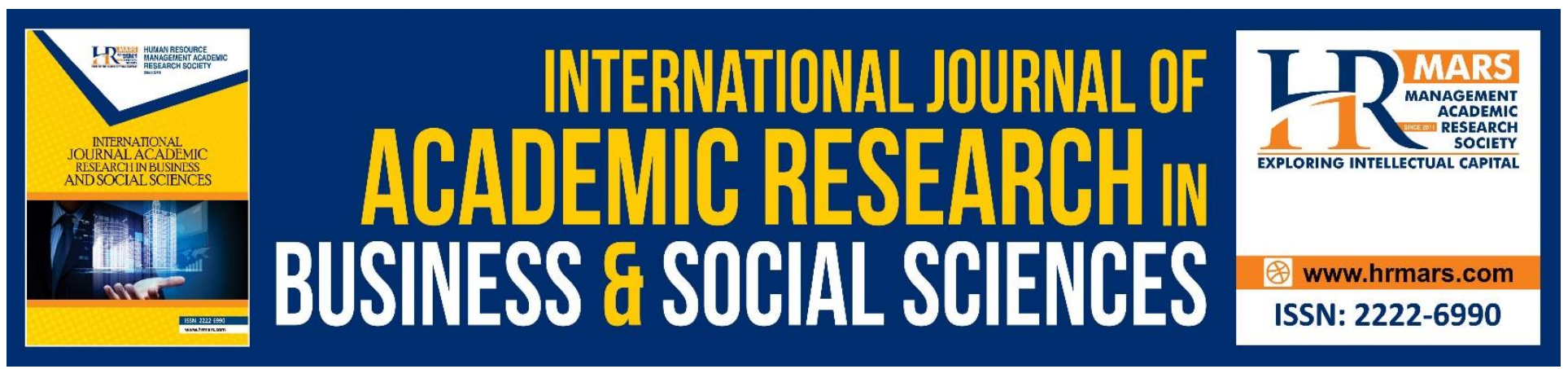

\title{
Occupational Stress, Job Satisfaction and Job Performance among Teachers: A Research Framework
}

\author{
Noor Liyana Mohd Nor \\ Faculty of Management and Information Technology, Postgraduate Studies Department \\ Sultan Azlan Shah University, 33000 Bandar Diraja Kuala Kangsar Perak, Malaysia
}

\begin{abstract}
This paper aims to develop a research framework of the relationship between occupational stress and job performance among teachers. Reading from prior literature, researchers found that job satisfaction mediated the relationship between occupational stress and job performance among teachers. Conclusion could be made after literature reviewed is that there is a significant relationship between occupational stress and job performance among teachers. If a teacher is under stress, they will be dissatisfied with their job and will perform poorly at school. Additionally, this research framework will be beneficial to the human resource management to improve the teachers' performance and future research is highly recommended.
\end{abstract}

Keywords: Occupational Stress, Job Satisfaction, Job Performance, Teacher.

\section{Introduction}

Effective and positive working environment is very crucial in terms of having a highly productive employee. High job satisfaction among employees is directly proportional to effective work. School is an organization known as a vital medium of transferring information and educating the nation. Under this educational field, there are teachers who are very important people to deliver information, knowledge and educate the nation to become better people. Teacher's role is crucial and if teachers are always under stress and dissatisfied with their job, the educational system would be ineffective, non-productive and would not be able to gain the goals in future (Kaur, 2017).

Teacher is one of the noble occupations in the world. They focus on the nation's growth with knowledge and determination. A good teacher can deliver their best to achieve the education's goals but stress would disturb the way. Stress faced by teachers would make an ineffective environment within the educational field. To achieve an effective environment, we must ensure that teachers are satisfied with their job. This satisfaction will encourage teachers to commit to deliver the knowledge and build up the nation in an effective and productive way. Also, when an employee is satisfied with their job, they will feel happy, develop themselves more efficient when doing work and will create 
success in their professional activity. Satisfaction will result in an employee to do work by his spirit of devotion and determination in order to fulfil the set goal (Panchal \& Yajurvedi, 2018).

Unfortunately, teaching is the most stressful in the world today. While $75 \%$ of the researchers assess the stress level of various jobs, they identified that the teaching profession came in the top rank. Furthermore, stress at the academic level may be destructive in the educational system as nonproductive teachers who under stress and improper mind centred could not generate and deliver the knowledge (Doss, Rachel, Jarrar, \& AbuMadini, 2018). As education is a key of implementation and changes, it makes the teacher's profession tougher because of demand increasing due to a progressive shift in the role expectations (Thirupathi, Sudha, \& Gopalakrishnan, 2018).

This occupational stress will lead to dissatisfaction towards the teaching profession and will make the teaching and learning environment in school not efficient and productive. Not only that, teachers who are suffering with occupational stress from their interaction with some of the aspects such as resources, human relations, security, and recognition will produce different psycho-social dynamics in the form of frustration, conflict and anxiety (Kaur, 2017).

\section{Literature Review}

Increasing work complexities and its divergent demands may trigger stress at the workplace and it became a prominent and pervading element of the modern organizations (Hasan, 2014). Occupational stress is defined as disruptions in an individual's psychological and/or physiological homeostasis that force them to diverge from normally interacting with their jobs and working surroundings (Allen, Hitt, \& Greer, 1982). Stress or strain comes out from interference in the equilibrium between the employee demands and existing resources that they have (Hakanen, Bakker, \& Schaufeli, 2006). Stress is also defined as a state of tension when someone experiences tension from extraordinary demands, constraints or opportunities (Senthilkumar, 2018). Stress is also a phenomenon in which perception exists from an unbalanced situation when someone received a command but is unable to cope with his task successfully. This unbalanced situation is capable of leading teachers to experiencing stress and resulting in stress reactions (Yahaya \& Husain, 2009).

Stress is most likely to occur in conditions where there are high demands, less control in individuals, and limited support and help available for a person. When the body receives stressor, it can increase the level of stress (Samad, Hashim, Moin, \& Abdullah, 2010). The stress response (i.e., strain) is considered as the result of an interaction between people with their surroundings. In view of occupational stress, work environment, the people and strain are the specific elements of this tripartite transactional model (Guglielmi \& Tatrow, 1998).

In the teacher's stress point of view, it is defined as the unpleasant feeling, negative emotions such as anger, anxiety, tension, frustration or depression that result from some factors that came from their nature of work as a teacher (Kyriacou, 2001). In addition, any conditions can trigger job stress feelings within the teaching profession. In one sense, it may occur when teachers begin to feel their daily tasks are ever-growing (Senthilkumar, 2018). Kaur (2017) defined teachers' stress as a condition where teachers exposed to certain unwanted environmental factors that interfere with the normal routine life of teachers either exist within educational institutions (internal factors) or outside the educational institution (external factors), then give a bad impact to their job performance. Teaching profession is well-known as a very stressful job and they need to play variety roles such as supporting parent, disciplining taskmaster, stimulating actor and informative resource person (Kumari \& Sood, 2017). 
Research done in Kenya has found that occupational stress has a significant impact in lowering job satisfaction among primary school teachers. This shows that the majority of primary school teachers are not satisfied with their work and if given an opportunity, they tend to leave this teaching profession for other professions. Better working conditions for teachers are highly recommended. It is necessary to create a motivated workplace to make sure teachers who are qualified and very experienced are retained in the schools. Not only that, it is vital to note that reducing occupational stress among teachers will minimize turnover and burnout (Koros, Momanyi, \& Chakua, 2018).

High levels of occupational stress may lead to unhappy feelings when working and resulting to dissatisfaction with the job. Occupational stress may come from frustrated feelings when having problems with colleagues or society. Those kinds of feelings may have a negative impact on the organization. Person who feels stressed with the job, he will be unable to be a productive worker at the workplace and resulting in a deficit in his efficiency while doing his job (Yaacob \& Long, 2015).

Teachers under stress will result in less job performance. Then will tend to act unwanted behaviours like absenteeism, mistakes during work and do violence at work impact from dissatisfaction and unmotivated (Ananthasayanan \& Subramaniam, 2013). Moreover, impact from occupational stress experienced by teachers will reveal a serious problem to teacher's motivation, their well-being and also quality of education. Teachers who are exhausted, do not share the objectives and values of the school, who are forced to use a teaching method that they are uncomfortable with and tends to leave the teaching profession as soon as possible are some of the possible outcomes from unsatisfied teachers with work. They also may show less patience, unwilling to change their teaching practices, spend minor time preparing for the class and are less sensitive to their students' needs (Skaalvik \& Skaalvik, 2015).

Job performance is also one of the crucial elements that has been given serious attention in both psychological and human resources management fields (Johari, Tan, \& Zulkarnain, 2018). High levels of stress will contribute a negative impact to our physical and mental health, resulting in bad performance (Senthilkumar, 2018). From previous literature, it seems that job satisfaction mediates the relationship between occupational stress and job performance among teachers. When teachers experience high levels of stress, they feel dissatisfied then will result in poor performance at work. Unfortunately, research on the relationship between occupational stress among teachers and their job performance by mediating with job satisfaction were scarce. Therefore, the relationship needed to be tested whether there is a significant relationship between occupational stress and job performance. Moreover, the result from prior research with different demographics will also be a significant factor for future research to be conducted.

The research framework in Figure 1 will propose the relationship between occupational stress, job satisfaction and job performance among teachers. In this study, the independent variable is occupational stress, the dependent variable is job performance and the mediating variable between independent and dependent variable is job satisfaction. 


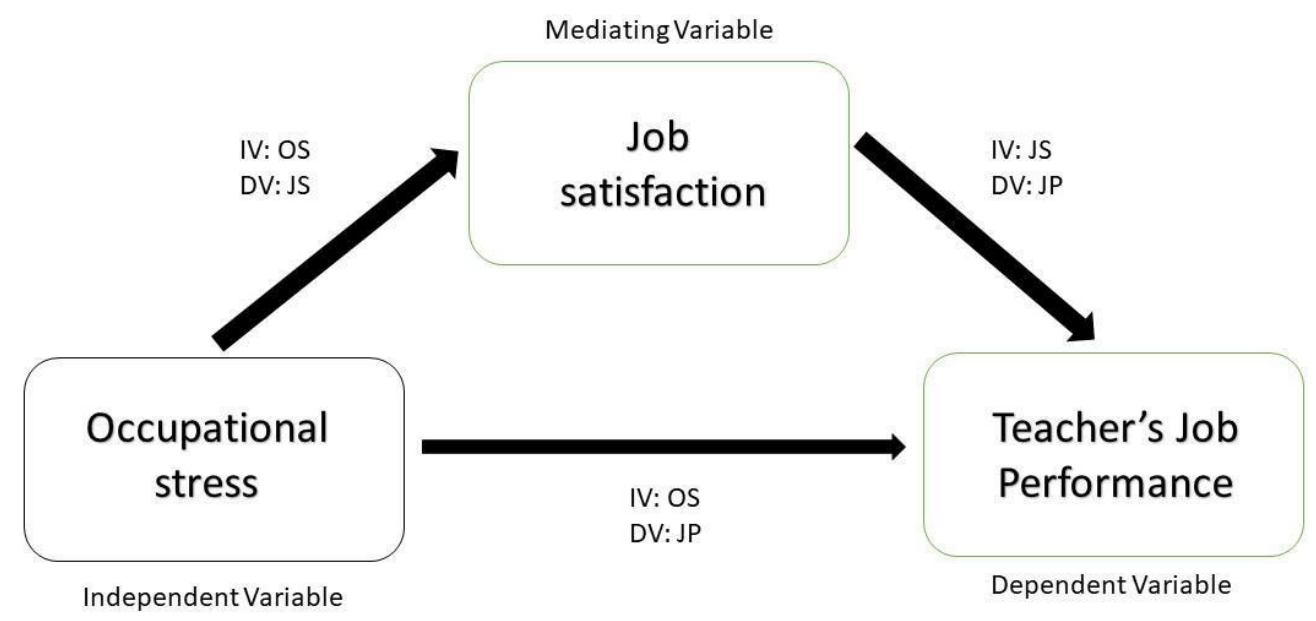

Figure 1: Research Framework

\section{Conclusion}

In this paper, the study highlights the relationship between occupational stress, job satisfaction and job performance among teachers. Previous literature concluded that, when teachers experience high levels of occupational stress, it will affect their performance to be less productive and effective (Yaacob \& Long, 2015). Teachers who are under stress will feel not satisfied with the job and will result in poor performance in an organization. Therefore, this proposed research framework is recommended to be tested in future research.

\section{References}

Allen, R. D., Hitt, M. A., \& Greer, C. R. (1982). Occupational Stress and Perceived Organizational Effectiveness in Formal Groups: An Examination of Stress Level and Stress Type. Personnel Psychology, 35, 359-370.

Ananthasayanan, S., \& Subramaniam, V. A. (2013). Effect of Stress on Teachers' Performance with Special Reference to Jaffna District Schools. International Conference - University of Sairam, 110. Retrieved from http://ssrn.com/abstract $=2386067$

Doss, C. A. V., Rachel, J. J., Jarrar, M. K., \& AbuMadini, M. S. (2018). A Comparative Study to Determine the Occupational Stress Level and Professional Burnout in Special School Teachers Working in Private and Government Schools. Global Journal of Health Science, 10(3), 42-53. https://doi.org/10.5539/gjhs.v10n3p42

Guglielmi, R. S., \& Tatrow, K. (1998). Occupational Stress, Burnout, and Health in Teachers: A Methodological and Theoretical Analysis. Review of Educational Research, 68(1), 61-99.

Hakanen, J. J., Bakker, A. B., \& Schaufeli, W. B. (2006). Burnout and Work Engagement among Teachers. Journal of School Psychology, 43, 495-513. https://doi.org/10.1016/j.jsp.2005.11.001 Hasan, A. (2014). A Study of Occupational Stress of Primary School Teachers. Educationia Confab, 3(4), 11-19.

Johari, J., Tan, F. Y., \& Zulkarnain, Z. I. T. (2018). Autonomy, Workload, Work-life Balance and Job Performance among Teachers. International Journal of Educational Management, 32(1), 107120. https://doi.org/10.1108/IJEM-10-2016-0226

Kaur, H. (2017). A Study of Teacher Effectiveness in Relation to Occupational Stress and Life 
INTERNATIONAL JOURNAL OF ACADEMIC RESEARCH IN BUSINESS AND SOCIAL SCIENCES

Vol. 10, No. 5, May, 2020, E-ISSN: 2222-6990 @ 2020 HRMARS

Satisfaction among Teacher Educators. International Journal Advances in Social Science and Humanities Harpreet Kaur/ August, 5(8), 1-9.

Koros, E. J., Momanyi, J. M., \& Chakua, C. K. (2018). The Impact of Occupational Stress on Job Satisfaction Among Kenyan Primary School Teachers. International Journal of Scientific Research and Management, 6(01), 51-56. https://doi.org/10.18535/ijsrm/v6i1.el08

Kumari, N., \& Sood, A. (2017). Relationship between Occupational Stress among School Teachers. 6th International Conference on Recent Trends in Engineering, Science \& Management, 453-462.

Kyriacou, C. (2001). Teacher Stress: Directions for future research. Educational Review, 53(1), 27-35. https://doi.org/10.1080/00131910120033628

Panchal, M., \& Yajurvedi, N. (2018). Job Satisfaction among Teachers Working in Government and Private Schools: With Special Reference to Noida Region. Indian Journal of Applied Research, 8(6), 72-74.

Samad, N. I. A., Hashim, Z., Moin, S., \& Abdullah, H. (2010). Assessment of Stress and Its Risk Factors among Primary School Teachers in the Klang Valley, Malaysia. Global Journal of Health Science, 2(2), 163-171.

Senthilkumar, R. (2018). Job stress among Teachers in Arts and Science Colleges-a Study with Reference to Pudukkottai District of Tamil Nadu. The Research Journal of Social Sciences, 9(3), 84-97.

Skaalvik, E. M., \& Skaalvik, S. (2015). Job Satisfaction, Stress and Coping Strategies in the Teaching Profession-What Do Teachers Say? International Education Studies, 8(3), 181-192. https://doi.org/10.5539/ies.v8n3p181

Thirupathi, M., Sudha, M., \& Gopalakrishnan, S. (2018). Stress Management of Private School Teachers. The Research Journal of Social Sciences, 9(1), 114-128.

Yaacob, M., \& Long, C. S. (2015). Role of Occupational Stress on Job Satisfaction. Mediterranean Journal of Social Sciences, 6(2), 81-87. https://doi.org/10.5901/mjss.2015.v6n2s1p81

Yahaya, A., \& Husain, N. D. H. N. (2009). Stress Level and its Influencing Factors among Secondary School Teachers in Johor, Melaka, Negeri Sembilan and Selangor. 